\title{
Pengembangan Media Pembelajaran Berbasis Permainan Monopoli Untuk Meningkatkan Keaktifan Siswa Pada Mata Pelajaran Sosiologi di SMAN 5 Bengkulu Utara
}

\author{
Berkah Adityo Szauli Putra ${ }^{1}$, Junaidi Junaidi ${ }^{2}$ \\ ${ }^{1,2}$ Universitas Negeri Padang \\ Email: berkahsp@gmail.com, junaidiunp@fis.unp.ac.id
}

\begin{abstract}
Abstrak
Penelitian ini bertujuan untuk mengetahui kelayakan, kepraktisan, dan keefektifan penggunaan media pembelajaran monopoli dalam pembelajaran sehingga mampu meningkatkan keaktifan peserta didik dalam proses belajar. Penelitian ini menggunakan metode penelitian Research and Development (R\&D) model $4 \mathrm{D}$, dengan empat langkah utama yang terdiri atas pendefinisian, perencanaan, pengembangan, dan penyebarluasan. Sampel dari penelitian ini adalah 32 siswa kelas X IPS 4 SMA N 5 Bengkulu Utara. Instrumen dalam penelitian ini menggunakan lembar validasi media, lembar validasi materi, angket respon/praktikalitas siswa atas media pembelajaran monopoli dan soal pree-test dan post-test siswa. Data dari pelaksaaan pembelajaran ini dianalisis menggunakan pedoman kriteria penelitian dalam bentuk presentase. Sedangkan data pre-test dan post-test dianalisa menggunakan T-hitung \& dari T-tabel. Berdasarkan hasil uji efektifitas t-hitung sebesar 34,40 dan t-tabel dengan $\mathrm{df}=\mathrm{N}-1$ atau $32-1=31$ dengan $a=0,05$ maka t-tabel 2,036 sehingga t-hitung > dari t-tabel. Hasil penelitian menunjukkan bahwa media pembelajaran monopoli layak digunakan sebagai media pembelajaran yang mampu meningkatkan keaktifan peserta didik pada mata pelajaran Sosiologi dengan hasil validitas sebesar 93\% yang berarti "Sangat Layak", serta hasil praktikalitas media sebesar $82 \%$ yang berarti "Baik".
\end{abstract}

Kata kunci: Keaktifan, Media Pembelajaran, Permainan Monopoli.

\section{Abstract}

This study aims to determine the feasibility, practicality, and effectiveness of using monopoly learning media in learning so as to increase the activeness of students in the learning process. This study uses the $4 D$ Model Research and Development (R\&D) research method, with four main steps consisting of defining, planning, developing, and disseminating them. The research subjects were 32 students of class X IPS 4 SMA N 5 Bengkulu Utara. The instrument in this study used media validation sheets, material validation sheets, student response / practicality questionnaires on monopoly learning media and student pre-test and post-test questions. The data from this learning exercise were analyzed using the research criteria guidelines in the form of a percentage. While the pre-test and post-test data were analyzed using $T$-count \& from T-table. The results showed that the monopoly learning media was feasible to use as a learning medium that was able to increase the activeness of students in the Sociology subject with the ratio of T-count $>T$-Table.

Keywords: Student Activity, Skills Learning Media, Monopoly Game.

Received: May 3, 2021

Revised: May 27, 2021

Accepted: May 28, 2021

\section{Pendahuluan}

Pembelajaran Sosiologi sebagai salah satu pembelajaran yang bersifat abstrak tidak cukup disampaikan dengan teori dan menemukan jawaban saja, namun perlu adanya media karena pada pendidikan abad 21 media yang digunakan harus menuntut peserta didik pada critical thinking dan problem solving, global awareness, collaboration, communication, innovation, serta creativity (Marjohan, 2013). Tidak hanya dituntut untuk memiliki pemahaman konsep dan teori dalam pembelajaran sosiologi, seorang peserta didik juga diharapkan dapat bekerja sama serta aktif dalam 
pembelajaran (Vermana, D. Y., \& Sylvia, 2019).

Siswa yang aktif mempunyai beberapa kriteria, diantaranya adalah mempunyai antusiasme dalam pembelajaran yang ditandai dengan keaktifannya dalam bertanya baik kepada guru maupun siswa lain, mempunyai dorongan yang kuat untuk mengerjakan tugas dari guru, dan mampu memberi jawaban atas pertanyaan dari guru (Rosalia, 2013). Dalam pembelajaran, keanekaragaman keaktifan siswa dapat berupa aktifitas fisik yang dapat diamati hingga aktifitas psikis yang tidak dapat diamati. Aktifitas fisik yang bisa diamati maksudnya seperti mengukur, memeragakan, menulis, mendengar, dan membaca. Sedangkan untuk aktifitas psikis yang tidak dapat diamati berupa aktifitas mengingat, menyimpulkan hasil percobaan, membandingkan beberapa konsep, serta kemampuan pemecahan masalah berdasarkan pengetahuan yang dimiliki, dan sebagainya (Mujiono, 2006).

Media pembelajaran mempunyai definisi sebagai sebuah proses penyaluran informasi dari pemberi ke penerima yang menstimulus kemauan, minat, perhatian, perasaan, dan fikiran peserta didik agar tujuan dalam proses pembelajaran dapat dicapai dengan efektif ((Sukiman, 2012). Media pembelajaran merupakan kegiatan menyusun dan merencanakan sebuah pola yang dijadikan acuan dalam perencanaan pembelajaran dikelas. Media pembelajaran adalah suatu pola atau rancangan yang dipergunakan untuk mendesain tatap muka di dalam kelas. Media pembelajaran juga menjelaskan beberapa langkah dan prosedur yang akan dilaksanakan dalam tatap muka di kelas. Secara umum, media pembelajaran dapat disimpulkan sebagai sebuah acuan atau pedoman berinteraksi dalam penyampaian materi pembelajaran dari guru ke peserta didik. Dalam hal ini berkaitan pula dengan penggunaan strategi atau teknik guru dalam mencapai target tujuan pembelajaran (Maksum, 2014).

Salah satu bentuk media pembelajaran yang bisa dimanfaatkan dalam usaha peningkatan keaktifan peserta didik ialah Permainan Monopoli. Media ini menerapkan konsep bermain sambil belajar, sehingga siswa akan tertarik serta aktif di dalam proses pembelajaran. Peserta didik juga akan dituntut berpikir serta aktif dalam melakukan media pembelajaran permainan monopoli ini.

Kenyataannya keaktifan siswa dalam belajar masih rendah. Salah satunya di kelas X IPS 4 SMAN 5 Bengkulu Utara, Bengkulu. Pernyataan ini didasarkan pada hasil observasi dan pengamatan pada proses pembelajaran yang dilaksanakan pada tanggal 15, 16, dan 17 Februari 2020,data awal diperoleh melalui hasil belajar siswa dan pernyataan langsung dari guru mata pelajaran Sosiologi. Dari permasalahan di atas peneliti melihat bahwa diperlukan sebuah pengembangan media pembelajaran berbasis permainan monopoli untuk optimalisasi peningkatan kaktifan peserta didik. Media permainan monopoli adalah media yang dapat menarik perhatian siswa karena mengandung unsur melihat dan bekerjasama.

\section{Metode Penelitian}

Pelaksanaan penelitian ini menggunakan metode Research \& Development (R\&D). Metode $\mathrm{R}$ \& D merupakan metode yang dipakai untuk menghasilkan sebuah produk atau untuk melihat tingkat efektifitas dari produk (Sugiyono, 2012). Menurut (Putra, 2012) hal dasar dalam model pengembangan ini berupa prosedur, konsep dan teori. Dan pada penelitian ini penulis memilih model prosedur karena lebih cocok dengan tujuan penelitian.

Pada penelitian ini, permainan monopoli yang akan dikembangkan menggunakan Model pengembangan 4-D. Model ini merupakan model pengembangan untuk perangkat pembelajaran yang tahapannya terdiridari pendefinisian (define), perencanaan (design), pengembangan (develop) dan diseminasi (disseminate). (Thiagarajan, 1947).

Tahap define, dalam tahap ini syarat-syarat pembelajaran ditetapkan melalui berbagai analisis. Analisis pada tahap ini dilakukan untuk penetapan berbagai tujuan serta batasan bahanbahan pembelajaran diantaranya analisis awal, analisis peserta didik, analisis tugas, analisis konsep dan analisis tujuan pembelajaran.Tahap design, Pada tahap ini peneliti merancang media

Jurnal Sikola: Jurnal Kajian Pendidikan dan Pembelajaran Vol. 2, No. 4, Th. 2021 
pembelajaran dan instrumen pengumpulan data yang akan divalidasikan ke para ahli diantaranya validator ahli media dan validator ahli materi.Tahap develop, tahap ini memiliki tujuan untuk mendapatkan justifikasi penilaian serta masukan dalam pengembangan media permainan berbasis monopoli agar media tersebut lebih efektif dan sesuai dengan tujuan pembelajaran.

Penggunaan media yang telah dikembangkan dilakukan pada tahap disseminate (penyebarluasan). Penyebarluasan dapat dilakukan dengan cara media pembelajaran yang telah dikembangkan didistribusikan kepada guru dan siswa. Distibusi ini dilaksanakan untuk mendapatkan respon atas media permainan monopoli yang telah dikembangkan. Produk yang didistribusikan tidak lain adalah produk akhir berupa media pembelajaran berbasis permainan monopoli yang sudah dinyatakan layak dan akan diberikan pada guru di SMA N 5 Bengkulu Utara.

Validitas materi, media, dan keefektifan media dicari dengan menggunakan penyebaran angket kepada ahli materi, ahli media, serta peserta didik. Sampel dalam penelitian ialah peserta didik kelas X IPS 4 SMA N 5 Bengkulu Utara yang sedang mempelajari materi penyimpangan social sesuai dengan media permainan monopoli yang peneliti kembangkan.

Rumus yang digunakan dalam Teknik Analisa data menggunakan rumus Analisa validitas dengan mencari rata-rata empiris.

$$
\begin{aligned}
& x=\frac{\sum x}{\mathrm{n}} \\
& \text { Keterangan: } \\
& \mathrm{x}=\text { rata }- \text { rata } \\
& \sum x=\text { jumlah nilai } \\
& \mathrm{n}=\text { jumlah responden }
\end{aligned}
$$

Persentase setiap sub variabel dihitung menggunakan formula:

$$
P(s)=\frac{s}{N} \mathrm{X} 100 \%
$$

Keterangan:

$$
\begin{aligned}
& P(s)=\text { persentase sub-variabel } \\
& \mathrm{S} \quad=\text { total skor tiap sub variabel } \\
& \mathrm{N} \quad=\text { total skor maksimun }
\end{aligned}
$$

Tabel 1. Kriteria Interpretasi uji validitas, Praktikalitas

\begin{tabular}{ccc}
\hline No. & Presentase & Kriteria \\
\hline 1. & $81-100 \%$ & Sangat baik \\
\hline 2. & $61-80 \%$ & Baik \\
\hline 3. & $41-60 \%$ & Cukup baik \\
\hline 4. & $21-40 \%$ & Kurang baik \\
\hline 5. & $0-20 \%$ & Sangat tidak baik
\end{tabular}

Sumber: Ridwan (Riduwan, 2012)

Berikutnya, kepraktisan media dicari dengan formula berikut. 


$$
x=\frac{2 x}{n}
$$

Kepraktisan media dapat dapat dianalisa dengan kriteria seperti berikut (Riduwan, 2012):

$5=$ Sangat Praktis

$4=$ Praktis

$3=$ Cukup Praktis

$2=$ Kurang Praktis

$1=$ Tidak Praktis

Di samping itu, validitas media akan dicari niainya dengan memanfaatkan rumus berikut.

$$
t=\frac{m d}{\sqrt{\frac{\sum x^{2} d}{N(N-1)}}}
$$

Rumus uji t ini digunakan untuk mengolah data efektifitas dari hasil pretest dan posttest.

\section{Hasil dan Pembahasan}

\section{Tahap Pendefinisian (Define)}

Analisis awal yang dilakukan yaitu observasi di SMA N 5 Bengkulu Utara pada 15,16,17 Februari 2020. Tujuan kegiatan ini tidak lain ialah untuk mendapatkan informasi berupa gambaran kondisi dan situasi di sekolah berkaitan dengan penelitian yang dilakukan. Observasi dilaksanakan melalui wawancara pada guru mata pelajaran serta pengamatan secara langsung pada waktu pelaksanaan pembelajaran di kelas X IPS 4 SMAN 5 Bengkulu Utara. Proses wawancara meliputi media pembelajaran serta proses pembelajaran yang digunakan serta respon peserta didik di dalam kelas. Informasi yang didapatkan berdasarkan hasil wawancara dan observasi mengenai tidak adanya variasi penggunaan media dan model pembelajaran yang satu arah yakni metode ceramah saja sehingga tidak meningkatnya keaktifan siswa saat proses pembelajaran.

Sebelum membuat rencana pengembangan media permainan monopoli, peneliti juga melakukan analisis karakteristik peserta didik. Penggunaan media pembelajaran monopoli ditujukan kepada 32 peserta didik kelas X IPS 4 SMAN 5 Bengkulu Utara. Keaktifan belajar siswa dapat dilihat dari beberpa aspek diantaranya : (1) Memerhatikan penjelasan guru, (2) Berdiskusi, (3) Bertanya, (4)Menjawab pertanyan, (5) Menanggapi, (6) Mencatat atau menulis, (7) Memecahkan masalah. Berdasarkan hasil observasi awal dapat diketahui bahwa keaktifan belajar siswa termasuk pada kategori rendah. Hal ini dibuktikan dengan keterlibatan siswa dalam belajar, dari 32 peserta didik kelas X IPS 4 SMAN 5 Bengkulu Utara terdapat 10 orang siswa yang memperhatikan penjelasan guru, 12 siswa yang aktif berdiskusi, 5 siswa yang aktif bertanya, 9 siswa yang aktif menjawab pertanyaan, 10 siswa yang aktif menanggapi, 20 siswa yang aktif mencatat atau menulis dan 5 siswa yang aktif memecahkan masalah. Keaktifan siswa jika dipresentasekan berdasarkan kriteria kemampuan berpikir kritis siswa adalah 10,14\% ( sangat rendah).

\section{Tahap Perencanaan (design)}

Instrumen yang disusun merupakan instrumen validasi media monopoli yang akan diserahkan kepada para ahli sebagai validator. Instrumen meliputi validasi ahli media yang diberikan kepada validator secara online via whatsapp. Adapun validator media monopoli adalah dua orang dosen Sosiologi Fakultas Ilmu Sosial Universitas Negeri Padang. Instrumen selanjutnya adalah instrumen validasi ahli materi oleh guru Sosiologi SMAN 5 Bengkulu Utara yang diberikan 
secara langsung saat akan melaksanakan penelitian. Instrumen selanjutnya adalah lembar praktikalitas yang akan diberikan kepada seluruh siswa X IPS 4 SMAN 5 Bengkulu Utara. Ketiga instrumen validasi tersebut disebarkan untuk melihat kelayakan dan kepraktikalitasan media monopoli dalam meningkatkan keaktifan siswa kelas X IPS 4. Selain instrumen validasi, dibuat juga instrumen berupa soal pretest dan posstest serta RPP.

\section{Tahap Pengembangan (Development)}

\section{Tahap Validitas Produk}

a. Uji validitas media

Berikut hasil validasi media monopoli telah dinilai oleh dua orang pakar dosen dari Jurusan Sosiologi FIS UNP. Hasil uji validasi media monopoli diperoleh sebagai berikut:

\section{Tabel 2. Hasil Uji ValidasiPenilaian Ahli Media}

\begin{tabular}{|c|c|c|c|c|}
\hline \multirow{2}{*}{ No } & \multirow{2}{*}{ Aspek } & \multirow{2}{*}{ Indikator } & \multicolumn{2}{|c|}{ Skor } \\
\hline & & & Ahli 1 & Ahli 2 \\
\hline \multirow[t]{12}{*}{1} & \multirow[t]{12}{*}{ Tampilan } & Jenis bahan yang digunakan bagus dan kuat. & 4 & 4 \\
\hline & & Huruf untuk permainan monopoli mudah dibaca. & 4 & 4 \\
\hline & & Ukuran huruf yang dipakai mudah dibaca. & 4 & 4 \\
\hline & & $\begin{array}{l}\text { Warna yang digunakan dalam media ini sesuai dan } \\
\text { tidak mencolok. }\end{array}$ & 4 & 4 \\
\hline & & $\begin{array}{l}\text { Komposisi warna, gambar, serta tulisan sesuai dengan } \\
\text { media. }\end{array}$ & 4 & 4 \\
\hline & & Gambar yang digunakan jelas dan ukurannya sesuai. & 4 & 4 \\
\hline & & Setiap kolom mempunyai peluang yang sama & 4 & 4 \\
\hline & & $\begin{array}{l}\text { Media yang dikembangkan terdapat inovasi dari media } \\
\text { yang sudah ada. }\end{array}$ & 3 & 3 \\
\hline & & $\begin{array}{l}\text { Media yang dikembangkan dapat digunakan untuk } \\
\text { semua materi pembelajaran. }\end{array}$ & 3 & 3 \\
\hline & & Media mudah dibawa serta disimpan. & 3 & 3 \\
\hline & & Media mudah digunakan. & 4 & 4 \\
\hline & & Media dapat menarik perhatian siswa. & 4 & 4 \\
\hline
\end{tabular}

Sumber: Data Primer 2021

Berdasarkan hasil validasi media oleh validator, pada indikator "jenis bahan yang digunakan bagus dan kuat" rerata skor yang didapat ialah 4,0 dengan tingkat validasi $80 \%$, pada indikator "huruf untuk permainan monopoli mudah dibaca" didapat rerata skor 4,0 dengan tingkat validasi $80 \%$, pada indikator "ukuran huruf yang digunakan mudah dibaca" rerata skor yang didapat 4,0 dengan tingkat validasi $80 \%$, pada indikator "komposisi warna, gambar, serta tulisan sesuai dengan media" didapat rerata skor 4,0 dengan tingkat validasi $80 \%$, pada indikator "gambar yang digunakan jelas dan ukurannya sesuai" rerata skor yang didapat sebesar 4,0 dengan tingkat validasi $80 \%$, pada indikator "setiap kolom mempunyai peluang yang sama" rerata skor yang didapat ialah 4,0 dengan tingkat validasi $80 \%$, pada indikator "media yang dikembangkan terdapat inovasi dari media yang sudah ada" rerata skor yang didapat 3,0 dengan tingkat validasi $60 \%$, pada indikator "Media yang dikembangkan dapat digunakan untuk semua materi pembelajaran" rerata skor yang didapat 3,0 dengan tingkat validasi $60 \%$, pada indikator "media mudah dibawa serta disimpan" rerata skor yang didapat ialah 3,0 dengan tingkat validasi $60 \%$, pada indikator "media mudah digunakan" rerata skor yang didapat ialah 4,0 dengan tingkat validasi $80 \%$, selanjutnya pada indikator terakhir "media dapat menarik perhatian siswa" didapat rerata skor sebesar 4,0 dengan 
tingkat validasi $80 \%$. Rerata skor secara keseluruhan pada aspek media sebesar 4,5 dengan tingkat validasi $90 \%$, hasil ini berarti media yang dikembangkan ada pada kriteria "sangat baik".

\section{b. Uji validitas materi}

Tabel 3. Penilaian Ahli Materi

\begin{tabular}{lllc}
\hline No & \multicolumn{1}{c}{ Aspek } & \multicolumn{1}{c}{ Indikator } & Skor \\
\hline 1 & Kesesuaian format & $\begin{array}{l}\text { Format media disajikan sesuai dengan standar } \\
\text { format media. }\end{array}$ & 5 \\
\hline 2 & $\begin{array}{l}\text { Kesesuaian dengan KI, KD } \\
\text { tujuan pembelajaran dan } \\
\text { IPK }\end{array}$ & $\begin{array}{l}\text { Materi yang disajikan sesuai dengan yang } \\
\text { terbendung dalam KI, KD, tujuan pembelajaran } \\
\text { serta IPK. }\end{array}$ & 5 \\
\cline { 3 - 5 } & $\begin{array}{l}\text { Materi yang disajikan sesuai dengan silabus } \\
\text { Kesesuaian media dengan } \\
\text { model pembelajaran }\end{array}$ & $\begin{array}{l}\text { Media yang disajikan sesuai dengan model } \\
\text { pembelajaran }\end{array}$ & 5 \\
\hline 3 & $\begin{array}{l}\text { Kesesuaian media dengan } \\
\text { RPP }\end{array}$ & Media yang disajikan sesuai dengan RPP & 5 \\
\hline 4
\end{tabular}

Sumber: data primer 2021

Berdasarkan hasil yang didapatkan dari validasi materi pada aspek kesesuaian format, ratarata skor yang diperoleh 5,0 dengan tingkat validasi $100 \%$, selanjutnya pada aspek kesesuaian media dengan $\mathrm{KI}, \mathrm{KD}$, tujuan pembelajaran dan IPK, rata-rata skor yang diperoleh 5,0 dengan tingkat validasi $100 \%$, pada aspek kesesuaian media dengan model pembelajaran, rata-rata skor yang diperoleh 4,0 dengan tingkat validasi $80 \%$, terakhir pada aspek kesesuaian media dengan RPP, rata-rata skor yang diperoleh 5,0 dengan tingkat validasi $100 \%$. Rata-rata skor secara keseluruhan hasil validasi materi adalah 4,8 dengan tingkat validasi $96 \%$ hasil ini berarti media yang dikembangkan ada pada kriteria "sangat baik".

c. Uji Praktikalitas Media

Pada tahap ini validasi Praktikalitas media permainan monopoli oleh peserta didik kelas $\mathrm{X}$ IPS 4 SMAN 5 Bengkulu Utara yang berjumlah 32 siswa. Hasil praktikalitas media permainan monopoli ditunjukkan oleh tabel berikut.

Tabel 4. Hasil Uji Praktikalitas

\begin{tabular}{cllll}
\hline No & \multicolumn{1}{c}{ Aspek } & Rata-rata & Persentase & \multicolumn{1}{c}{ Keterangan } \\
\hline 1 & Media yang disajikan sangat menarik & 4,0 & $80 \%$ & Baik \\
\hline 2 & Media yang disajikan jelas dan terstruktur & 4,2 & $84 \%$ & Sangat Baik \\
\hline 3 & Memudahkan siswa dalam pembelajaran & 3,8 & $76 \%$ & Baik \\
\hline 4 & Efektif dalam pembelajaran & 4,1 & $82 \%$ & Sangat baik \\
\hline 5 & Dapat meningkatkan keaktifan & 4,4 & $88 \%$ & Sangat baik \\
\hline \multicolumn{2}{c}{ Jumlah } & 4,1 & $82 \%$ & Sangat baik \\
\hline
\end{tabular}

Sumber: Data Primer 2021

Dari tabel hasil praktikalitas peserta didik, aspek "media yang disajikan sangat menarik" rerata skor yang didapat sebesar 4,0 dengan tingkat validitas $80 \%$, pada aspek "media yang disajikan jelas dan terstruktur" rerata skor yang didapat sebesar 4,2 dengan tingkat validitas $84 \%$, pada aspek "memudahkan siswa dalam pembelajaran" rerata skor yang didapat sebesar 3,8 dengan tingkat validitas $76 \%$, pada aspek "efektif dalam pembelajaran" rerata skor yang didapat sebesar 4,1 dengan tingkat validitas $82 \%$ dan pada aspek terakhir "dapat meningkatkan keaktifan" rerata skor yang didapat sebesar 4,4 dengan tingkat validasi $88 \%$. Rata-rata skor hasil praktikalitas peserta 
didik secara keseluruhan adalah 4,1 dengan tingkat validitas $82 \%$ hasil ini berarti media yang dikembangkan ada pada kriteria "sangat baik".

\section{d. Uji Efektivitas}

Berdasarkan hasil pretest dan posttest siswa media yang dikembangkan diuji efektivitasnya di kelas X IPS 4 SMAN 5 Bengkulu Utara. Pengujian ini dilaksanakan dengan menggunakan desain eksperimen one group pre-test dan post-test, yang berarti pengujian hanya dilaksanakan pada satu kelas saja. Dari hasil pengujian diperoleh $t_{\text {hitung }}$ sebesar 34,40 dan $t_{\text {tabel }}$ dengan $\mathrm{df}=\mathrm{N}-1$ atau 32-1 $=$ 31 dengan $\alpha 0,05$ maka $t$ tabel 2,036 sehingga $t_{\text {hitung }}>$ dari table. Hasil ini memperlihatkan bahwa hasil pre-test dan post-test siswa sebelum dan setelah menggunakan media permainan monopoli materi penyimpangan sosial mendapatkan perbedaan yang signifikan. Melalui hasil ini juga dapat dikatakan bahwa media monopoli hasil pengembangan efektif, praktis, dan valid. Media ini juga memiliki pengaruh dalam peningkatan keaktifan belajar peserta didik pada meteri penyimpangan sosial mata pelajaran sosiologi.

\section{Pembahasan}

Tema penelitian ini adalah pengembangan media pembelajaran permainan monopoli untuk meningkatkan keaktifan peserta didik pada mata pelajaran Sosiologi di SMAN 5 Bengkulu Utara. Ada tiga hal pokok yang dibahas diantaranya adalah untuk mengetahui kelayakan, kepraktisan, serta keefektifan penggunaan media pembelajaran monopoli dalam pembelajaran agar dapat mendorong peningkatan keaktifan peserta didik dalam proses pembelajaran. Pengembangan media ini menggunakan model pengembangan 4-D yang terdiri atas empat langkah utama yakni define, design, development, dan disseminate.

Penelitian ini dilakukan secara tatap muka dikelas X IPS 4 SMAN 5 Bengkulu Utara dengan tiga kali pertemuan. Pada pertemuan pertama, peserta diberikan pretest serta penjelasan mengenai tujuan pembelajaran dan menjelaskan mengenai definisi perilaku menyimpang, pertemuan kedua peneliti melanjutkan menjelaskan materi tentang ciri-ciri, jenis-jenis serta teori perilaku menyimpang, pada pertemuan ketiga peneliti menguji cobakan media permainan monopoli dengan membagi siswa dalam beberapa kelompok dan sekaligus peneliti memberikan angket parktikalitas serta memberikan posttest guna melihat apakah pengembangan produk yang dilakukan layak untuk digunakan serta dapat meningkatkan keaktifan siswa. Sebelum produk diuji cobakan media monopoli di validasi terlebih dahulu kepada dua orang validator dosen Sosiologi FIS UNP, dan validasi materi oleh guru mata pelajaran Sosiologi SMAN 5 Bengkulu Utara. Setelah mendapatkan data hasil validasi media dan materi, selanjutnya peneliti melakukan pengolahan data, hasil pengolahan data menunjukan bahwa media permainan monopoli mendapat rata rata validasi sebesar $93 \%$ yang artinya layak dan bisa digunakan dalam pembelajaran.

\section{Kesimpulan}

Pengembangan media permainan monopoli ini menghasilkan media pembelajaran berbasis permainan monopoli yang memiliki kelayakan untuk digunakan dalam meningkatkan keaktifan peserta didik pada materi penyimpangan sosial pada pembelajaran Sosiologi kelas X. Dari hasil uji validasi oleh para ahli, media permainan monopoli mempunyai kriteria "sangat layak".hasil uji coba awal juga menunjukkan bahwa media pembelajaran berbasis permainan monopoli memenuhi kriteria "sangat layak", hasil penyebaran angket respon guru dan peserta didik pun menunjukkan bahwa media memiliki kriteria "sangat layak". Selanjutnya dari hasil uji coba di lapangan dengan angket respon guru dan siswa,media permainan monopoli materi penyimpangan sosial memenuhi kriteria efektifitas dengan kategori "sangat efektif" dan "sangat praktis". Di samping itu, terdapat perbedaan kemampuan berfikir peserta didik dalam pembelajaran materi penyimpangan sosial sebelum dan sesudah penggunaan media permainan monopoli. Hal ini 
ditunjukkan oleh hasil uji-t independen dengan nilai signifikansi $(p)<0,05$ yaitu sebesar 0,000, nilai $t$ hitung sebesar 34,40 dan $\mathrm{t}$ table sebesar 2,036 yang bermakna $\mathrm{t}$ hitung $>$ dari $\mathrm{t}$ tabel.

\section{Daftar Pustaka}

Maksum, M. (2014). Pengaruh Model Pembelajaran Kooperatif Tipe Numbered Head Together (NHT) Terhadap Hasil Belajar Pengetahuan Dasar Teknik Otomotif Siswa Kelas X TKR SMK Muhammadiyah 1 Padang. Universitas Negeri Padang.

Marjohan, M. (2013). Kepatuhan Siswa Terhadap Disiplin dan Upaya Guru BK dalam Meningkatnya Melalui Layanan Informasi. Ilmiah Konseling, 2(5), 220-224.

Mujiono, D. (2006). Belajar dan pembelajaran. Jakarta: Rineka Cipta.

Putra, N. (2012). Research and Development. Jakarta: Raja Grafindo Persada.

Riduwan, R. (2012). Skala Pengukuran Variabel-variabel Penelitian. Bandung: Alfabeta.

Rosalia, T. (2013). Aktifitas Belajar. http://id.shvoong.com/social-sciences/1961162-aktifitasbelajar/

Sugiyono, S. (2012). Metode Penelitian Kuantitatif, Kualitatif dan $R \& D$. Bandung: Alfabeta. https://doi.org/10.1017/CBO9781107415324.004

Sukiman, S. (2012). Pengembangan Media Pembelajaran. Yogyakarta: Pedagogia.

Thiagarajan, S. (1947). Instructional Development For Training Teachers of Exceptional Children. Washinton DC: National Center for Improvement Educational System.

Vermana, D. Y., \& Sylvia, I. (2019). Penerapan Model Group Investigation dalam Meningkatkan Kemampuan Kerjasama Siswa Kelas XI IPS di SMA N 6 Padang. Jurnal Sikola: Jurnal Kajian Pendidikan dan Pembelajaran, 1(1), 60-68. 